\title{
Woodcock is Not a Dirty Word! Using Interest in Wildlife to Engage Private Forest Landowners
}

\author{
JEREMY HOLTZ, ${ }^{1}$ Wisconsin DNR, 107 Sutliff Avenue, Rhinelander, WI 54501
}

\begin{abstract}
Over the last half century, Wisconsin's young (or early successional) forest cover has decreased in extent and declined in quality as habitat for associated wildlife. Consequently, many wildlife species have seen population declines. A majority of Wisconsin's forests are privately owned, and the majority of forest owners report having no management plan. The Wisconsin Young Forest Partnership (WYFP) is a group of agencies, organizations, and businesses that have come together to enhance young forests across ownerships. Together we have developed a program that uses concern for and interest in wildlife species to begin a dialogue with landowners who currently are not actively managing their forests. Over the past 5 years, we have learned what does-and does not-work when trying to begin a dialogue with forest landowners in north-central Wisconsin. The goal of the WYFP is to increase the managed area of aspen (Populus spp.), alder (Alnus spp.), and associated young forest cover to reflect the habitat conditions that American woodcock (Scolopax minor), ruffed grouse (Bonasa umbellus), golden-winged warblers (Vermivora chrysoptera), and other species associated with early successional forest experienced in the 1970 a and 1980s. We connect landowners to resources such as natural resource professionals, trained consulting foresters, and, in many cases, habitat funds to pay for plan writing and habitat management. The end result is landowners who are excited about forest management, are actively engaged in forestry practices to improve wildlife habitat, and who have a written plan to help them continue management on their property into the future.
\end{abstract}

Proceedings of the American Woodcock Symposium 11: 93

KEY WORDS: American woodcock, forest cover, forest management, private forest landowners

FULL PAPER CitATION: Jeremy Holtz "Woodcock is Not a Dirty Word! Using Interest in Wildlife to Engage Private Forest Landowners," The Wildlife Professional, 12(1), 32-35 (February 2018). Available at https:// pubs.lib.umn.edu/index.php/aws/article/view/2365/1852

1 email: jeremy.holtz@wisconsin.gov 